\title{
Physicochemical basis of resistance in certain green gram genotypes to pulse bruchid, Calloso bruchus chinensis (L.)
}

\section{G. Kavitha}

Department of Seed Science and Technology Advanced Post Graduate Centre, Lam, Guntur- Andhra Pradesh.

M. S. Mahalakshmi 网

AICRP on Pulses, Regional Agricultural Research Station, Lam, Guntur- Andhra Pradesh.

K. Bayyapu Reddy

Department of Seed Science and Technology Advanced Post Graduate Centre, Lam, Guntur- Andhra Pradesh. Y. Pushpa Reni

AICRP on Pulses, Regional Agricultural Research Station, Lam, Guntur- Andhra Pradesh.

K. Radhika

Department of Seed Science and Technology Advanced Post Graduate Centre, Lam, Guntur- Andhra Pradesh.

\begin{tabular}{|c|c|}
\hline ARTICLE INFO & ABSTRACT \\
\hline $\begin{array}{l}\text { Received : } 22 \text { June } 2021 \\
\text { Revised : } 07 \text { September } 2021 \\
\text { Accepted : } 10 \text { September } 2021 \\
\text { Available online: } 9 \text { December } 2021 \\
\text { Key Words: } \\
\text { Bruchid } \\
\text { Greengram } \\
\text { Phenols } \\
\text { Proteins } \\
\text { Seed coat thickness }\end{array}$ & $\begin{array}{l}\text { A study was conducted to know the influence of physical and biochemical } \\
\text { parameters on development of the pulse bruchid in green gram at RARS, Lam } \\
\text { during } 2017-18 \text {. The physical parameters of seed viz., colour, shape, surface } \\
\text { texture, seed length and width, seed coat hardness and } 100 \text { seed weight and } \\
\text { biochemical parameters such as protein content, phenol content and total } \\
\text { sugars were evaluated for twelve genotypes of greengram. The greengram } \\
\text { genotypes with smooth texture, oblong or globose shape and light coloured seed } \\
\text { might be less preferred by the pulse bruchid for egg laying. The data showed } \\
\text { that genotypes having low sugar and protein contents and high phenol content } \\
\text { were resistant to pulse bruchid. The correlation studies showed that biological } \\
\text { parameters i.e., number of eggs, adult emergence and growth index had } \\
\text { significant positive association with protein content, sugar content, moisture } \\
\text { content and electrical conductivity and negative correlation phenol content, } \\
\text { 100 seed weight and seed coat hardness. In contrast, mean development period } \\
\text { had negative association with protein content, sugar content, electrical } \\
\text { conductivity and moisture content and positive correlation with phenol } \\
\text { content, } 100 \text { seed weight and seed coat hardness. Multiple linear regression } \\
\text { studies revealed that all the physical and biochemical properties of seed } \\
\text { together were contributing to a large and significant variation (65 to } 87 \text { \%) in } \\
\text { growth parameters of pulse bruchid. }\end{array}$ \\
\hline
\end{tabular}

\section{Introduction}

Pulses serve as one of the main sources of protein and minerals besides playing a vital socioeconomic role in the diet of common people of India. Among pulses, green gram is an important pulse crop in India. It contains $51 \%$ carbohydrates, $26 \%$ proteins, $4 \%$ minerals and $3 \%$ vitamins and sprouts arerich in vitamin-C and iron (Yadav et al., 1994). More than $70 \%$ of the world's greengram production comes from India (Usha et al., 2020) the farmers and traders mostly store the pulses at least for few months before they sell it. Unfortunately, in storage, pulses suffer enormous losses due to bruchid attack, which infestation starts either in the field on the maturing pod and is carried to the stores with the harvested crops or it originates in the storage itself (Fletcher and Ghosh, 2002). The genus Calloso bruchus is capable of breeding on a wide variety of legumes and attacks the grain legumes during both pre and post harvest stages. $C$. chinensis, $C$. maculatus and $C$. analis are the predominant species in India (Jat et al., 2013).The process of host selection and oviposition is mainly influenced by physical and biochemical properties of seed. The degree of resistance and susceptibility

Corresponding author E-mail: msmlaxmi@gmail.com

Doi: https://doi.org/10.36953/ECJ.2021.22328

This work is licensed under Attribution-Non Commercial 4.0 International (CC BY-NC 4.0)

(C) ASEA 
of different pulses to bruchid attack is influenced by various characteristics. The basis of resistance involves morphological, physiological and biochemical mechanisms which range from simply minimizing the effect of insect attack to adversely affecting the growth and development of insects (Singh, 2002). There are many accessions which exhibit wide range of physical and chemical characteristics such as seed color, texture, size, hardness and chemical constituents (Lattanzio et al., 2005). In many cases, it is obvious that the physical characters of seed and biochemical constituents such as phenols, tannins, trypsin inhibitor and amylase inhibitor are important in conferring resistance to bruchids. Most varieties of greengram are susceptible to pulse bruchid infestation leading to economic losses which include loss in seed weight as well as germination potential. Hence, the present investigation was taken up to understand the physical and biochemical basis of resistance in greengram to pulse bruchid.

\section{Material and Methods}

The studywas conducted under laboratory conditions at Regional Agricultural Research Station (RARS), Lam, Guntur, Andhra Pradesh and Department of Seed Science and Technology, Advanced Post Graduate Centre, Lam, Guntur. Twelve greengram genotypesi.e.,GGG-1, LGG407, LGG-450, LGG-460, LGG-574, LGG-586, LGG-595, LGG-607, LGG-610, PM-5, TM-92-2 and WGG-42 collected from the Regional Agricultural Research Station, Lam, Guntur were used in the study.

\section{Insect culture and maintenance}

The culture of pulse beetle (Callosobruchuschinensis) was obtained from the stock culture at Regional Agricultural Research Station, Lam, and Guntur. This culture maintained in plastic jars of one litre capacity containing greengram seed. The mouth of the jar was covered with muslin cloth and fastened tightly with the help of a rubber band. Freshly emerged insects from the culture were used for the experiment as no choice test. $100 \mathrm{~g}$ seed of each greengram genotype was taken in a plastic container of one kilogram capacity into which two pairs of freshly emerged bruchids were released. After collecting the adults from stock culture, they were kept in deep freezer for few minutes in order to inactivate counting and sexing. After introducing the bruchids into each jar, the mouth of the jar was secured with perforated lids. After three days, the adults were removed and data on oviposition was recorded. The data recorded at monthly interval upto eight months of storage on various biological parameters of pulse bruchid i.e., number of eggs laid, adult emergence, seed weight loss, mean development period and growth index. The experiment was laid out in Completely Randomized Design with three replications under ambient conditions.

\section{Physical Parameters}

Seed Colour: Seed colour was determined by comparing colour of the seed coat with different shades of various colours by visual examination and classified as green, dark green, light green, olive green and light olive green.

Seed Surface Texture: From each genotype hundred seed were selected randomly and texture was recorded by visual observation and classified as smooth, rough and wrinkled.

Seed Shape: From the same sample, observations were made on their shape and classified as ovoid, oblong, globose and cylindrical shaped.

Seed Length and Width (mm): Ten seed were taken from the each genotype and from each replication at random and the seed length and width was measured with the help of the vernier calipers and mean seed length and width was expressed in $\mathrm{mm}$.

Seed Coat Hardness (\%): The seed coat hardness was determined by the water absorption method and expressed as percentage increase in the seed weight. For this purpose, 20 seed were selected randomly and weighed, then soaked in $25 \mathrm{ml}$ of distilled water and incubated at $25^{\circ} \mathrm{C}$ for overnight. Water was decanted and seed was placed on blotter paper to remove the water adhering the surface and weighed again after 24 hours. The seed coat hardness was calculated by using the following formula:

Seed coat hardness $(\%)=\left\{\left(\mathrm{W}_{2}-\mathrm{W}_{1}\right) / \mathrm{W}_{1} \mathrm{X} 100\right\}$

Where,

$\mathrm{W}_{1^{-}}$Weight of seed before soaking in distilled water

$\mathrm{W}_{2^{-}}$Weight of seed after soaking in distilled water

100 Seed Weight: 100seed from each replication and treatment were chosen manually at random and their weight was recorded on precision balance 
(Model: DS-852G) and weight was expressed in grams.

Biochemical Parameters: The biochemical parameters viz., soluble protein content, total phenol content and total soluble sugar content in the seed of selected greengram genotypes were estimated before and eight months of insect infestation by using the following procedures:

Preparation of Sample: The seed samples of different genotypes were dried at $60{ }^{\circ} \mathrm{C}$ in a hot air oven for 3 days. Seeds were ground by using pestle and mortar. The powdered samples were sieved through a 100 mesh screen and stored in the sealed containers at $4{ }^{0} \mathrm{C}$, for analysis.

Soluble Protein Content: $100 \mathrm{mg}$ of oven dried powdered sample was extracted in $10 \mathrm{ml}$ of $0.1 \mathrm{M}$ sodium phosphate buffer, $\mathrm{pH} 7.0$ for one hour on a magnetic stirrer at room temperature. The extract was centrifuged at $10,000 \mathrm{rpm}$ for 20 minutes and the supernatant was used for the estimation of total soluble protein content. Protein content in greengram seed was estimated by using bovine serum albumin as per the standard method suggested by Lowry et al. (1951) in which $1 \mathrm{ml}$ aliquot sample was taken and to this $5 \mathrm{ml}$ of solution $\mathrm{C}[50 \mathrm{ml}$ of solution of $\mathrm{A}(20 \mathrm{~g}$ of anhydrous carbonate $\left(\mathrm{Na}_{2} \mathrm{CO}_{3}\right)$ and $4 \mathrm{~g}$ of sodium hydroxide

were dissolved in $1000 \mathrm{ml}$ of distilled water) was mixed with $1 \mathrm{ml}$ of solution $\mathrm{B}(1 \mathrm{ml}$ of 1.35 sodium potassium tartarate $\left(\mathrm{C}_{4} \mathrm{H}_{4} \mathrm{KNaO}_{6}{ }^{*}{ }^{4} \mathrm{H}_{2} 0\right)$ and $0.1 \mathrm{ml}$ of $5.5 \%$ copper sulphate $\left(\mathrm{CuSO}_{4} 5 \mathrm{H}_{2} \mathrm{O}\right)$ solutions were mixed together)] was added and mixed well. After 10 minutes, $0.5 \mathrm{ml}$ of Folin Ciocalteau Reagent was added and mixed the content immediately on a vortex mixer. The blue colour developed was measured at $660 \mathrm{~nm}$ after 30 minutes with spectrophotometer against a reagent blank. The protein content was calculated from a standard graph prepared by using bovine serum albumin solution $\left(20-200 \mathrm{~g} \mathrm{ml}^{-1}\right)$. The total soluble protein content was expressed as mg per gram of oven dried sample.

Total Phenol Content: $100 \mathrm{mg}$ of oven dried powdered sample was dissolved in $10 \mathrm{ml}$ of warm 80 per cent ethanol for one hour at room temperature, the extract was centrifuged at6000 rpm for 15 minutes and supernatant was collected in a $25 \mathrm{ml}$ volumetric flask. The extraction procedure was repeated thrice to get the phenol free sample and make the final volume to $25 \mathrm{ml}$ with 80 $\%$ ethanol. Phenol content from greengram seed was estimated using folin-ciocalteau reagent method suggested by Swain and Hillis (1959). An aliquot sample of $1 \mathrm{ml}$ was diluted to $7.5 \mathrm{ml}$ with distilled water and $0.5 \mathrm{ml}$ of diluted FCR was added and mixed. Exactly after 3 minutes, $1 \mathrm{ml}$ of saturated sodium carbonate solution was added and made upto a total volume of $10 \mathrm{ml}$ with distilled water and kept in a boiling water bath for one minute and then allowed to cool and was measured at $725 \mathrm{~nm}$ with spectrophotometer against the reagent blank. The phenol content was calculated from a standard graph prepared by using catechol as a standard in the range of $20-100 \mu \mathrm{g}$. The total phenol content was expressed as mg per gram of oven dried sample.

Total Soluble Sugar Content:100 mg of oven dried powdered sample was dissolved in $10 \mathrm{ml}$ of warm 80 per cent ethanol for one hour at room temperature, the extract was centrifuged at6000 $\mathrm{rpm}$ for 15 minutes and collected the filtrate in a 25 $\mathrm{ml}$ volumetric flask. Repeated the extraction procedure three times to get the sugar free and make the final volume to $25 \mathrm{ml}$ with $80 \%$ ethanol. Total soluble sugars in greengram samples were estimated by the method suggested by Dubois et al. (1956). An aliquot of $1 \mathrm{ml}$ was diluted to $10 \mathrm{ml}$ with distilled water. $2 \mathrm{ml}$ of 5 per cent phenol reagent and $5 \mathrm{ml}$ of 98 per cent $\mathrm{H}_{2} \mathrm{SO}_{4}$ was added and incubated for 10 minutes and then placed in water bath at $30{ }^{\circ} \mathrm{C}$ for 20 minutes. The absorbance was read at490 nm with spectrophotometer against the reagent blank. The sugar content was calculated from a standard graph prepared by using glucose solution as a standard in the range of $20-100 \mu \mathrm{g}$. The total soluble sugar content is expressed as $\mathrm{mg}$ per gram of oven dried sample.

\section{Statistical analysis:}

The data for physical and bio-chemical factors was collected by adopting Completely Randomized Design (Panse and Sukhatme, 1985) were subjected to appropriate transformations wherever necessary and analyzed using OP STAT software. The treatment means were compared using Duncan's multiple range test $(\mathrm{P}<0.05)$ using SPSS software (version 6.0 ) at $1 \%$ and $5 \%$ level of significance. Simple correlation coefficients and multiple 
regression analysis were worked out between physicochemical parameters and biological parameters of the test insect of greengram genotypes as suggested by Steel and Torrie (1980).

\section{Results and Discussion \\ Physical Parameters:}

Seed colour: Seed colour of greengram genotypes varied from green, thick green, olive green, light green, light olive green. Among the genotypes, five genotypes had green colour seeds, four has thick green, one genotype each with olive green, light green and light olive green coloured seeds (Table 1). PM-5 is the least preferred genotype by pulse bruchid which recorded a significantly lowest number of eggs (14.00 number / 100 seed), while WGG-42 was found to be a highly preferred host for egg laying by pulse bruchid with the significantly highest number of eggs (73.17 number / 100 seed) when compared to all the other genotypes over 8 months of storage (Table 2). From the data, it is evident that genotypes with thick colour seeds i.e., green and thick green colour are more preferred over light coloured seeds such as olive green or light green colour for egg laying by bruchids. However, no reports were available on influence of seed colour on bruchid infestation in greengram. But, dark tan brown coloured kidney bean seeds recorded more number of eggs than white colouredseeds (Chakraborty and Mandal, 2016).

Seed texture: Based on surface texture, the greengram genotypes under study were categorized into smooth, rough and wrinkled. Among the genotypes, six genotypes possessed smooth seed surface, 5 genotypes followed has rough seed surface and one genotype with wrinkled seed surface. The genotypes with rough and wrinkled surface recorded less number of eggs when compared to smooth surface. Thus, rough and wrinkled surface can be considered as resistance character of greengram genotypes against pulse bruchid(Table 1). The results are in concurrence with that of Satyavir (1980) and Singhal and Singh (1985) who opined that smooth seed were much preferred for oviposition. However, some reports rule out any role of seed coat in bruchid egg laying and resistance in mungbean (Somta et al., 2008). Shaheen (2006) also reported that the cultivars with hard, rough, wrinkled and thick seed coat were more resistant when compared with those having smooth, soft and thin seed coat.

Seed shape: Based on the shape, genotypes were categorized into four groups i.e., ovoid, cylindrical, globose and oblong. Observations showed that seven genotypes had ovoid shape, 3 genotypes had cylindrical and one genotype each with globose and oblong shaped seeds. The results showed that the genotypes with oblong and globose seed shape recorded lesser number of eggs when compared to cylindrical and ovoid shaped seed. Hence, it can be conferred that oblong and globose seed shape might be less preferred by the pulse bruchid for egg laying which leads to the less adult emergence and subsequently lower seed damage. However, no reports were available on influence of seed shape on bruchid infestation in greengram

Seed length: Seed length ranged from $3.79 \mathrm{~mm}$ (LGG 586) to $4.77 \mathrm{~mm}$ (PM 5) with significant differences among the genotypes. Similarly, seed width also differed significantly among the genotypes which ranged from 3.09 mmLGG-586 to $3.77 \mathrm{~mm}$ (PM 5). The seed length width ratio ranged from 1.15 to 1.32 with maximum in LGG450(1.32) followed by LGG-460 (1.31) and PM-5 (1.26) and minimum in GGG-1 (1.15) followed by LGG-610 (1.19) and LGG-595 (1.20) (Table 1). PM-5 is the least preferred genotype by pulse bruchid which recorded a significantly lowest number of eggs (14.00 number / 100 seed), while WGG-42 was found to be a highly preferred host for egg laying by pulse bruchid with the significantly highest number of eggs (73.17 number/ 100 seed) when compared to all the other genotypes at 8 months after storage. The present results clearly indicated that the seed length, width and length width ratio had significant influence on egg laying but coupled with other physical parameters. However, the influence of seed length or width on preference of pulse bruchid was not reported earlier.

Seed Coat Hardness (\%): Seed coat hardness was measured based on percentage weight increase by water absorption which ranged from 57.33 to 96.00 per cent among the greengram genotypes. Lower the water absorption, higher is the seed coat hardness. Seed coat hardness was high in PM-5 $(96.00 \%)$, while it was low in GGG-1 $(57.33 \%)$ with significant differences among the genotypes (Table 1).The data indicated that the genotypes 
with high seed coat hardness recorded less number of eggs, long mean development period and less weight loss andvice-versa. Thus the genotypes with more seed coat hardness are less preferred by pulse bruchid. The present results are in accordance with that of Rai and Singh (1989) who reported that yellow seed colour with smooth thin coats were more severely damaged than the small brown seed having hard coats in chickpea. In corroboration with results, Chakraborty and Mandal (2016) reported that ovopositional preference was dependent on the seed colour, seed texture, seed weight, thickness of seed coat, seed moisture and various chemical properties. Chakraborthy et al. (2004) also reported that thickness of seed coat had greater impact on the damage; thicker seed coat reduced the seed damage by pulse bruchid in mungbean.

100 Seed Weight (g): There was significant difference in 100 seed weight among the greengram genotypes. Weight of 100 seed or test weight was highest in PM-5 (4.87 g) and the lowest weight of $3.14 \mathrm{~g}$ was observed in LGG-407, LGG-574 and LGG-586 followed by WGG-42 (3.21 g), LGG-450 $(3.23 \mathrm{~g})$, LGG-595 (3.27 g) and TM-92-2 (3.30 g) (Table 1). It was observed that test weight had no significant influence on incidence of pulse bruchid. The present findings are in accordance with the results of Dabi et al. (1979) who reported that the weight of seed had no effect on the resistance or susceptibility of the cowpea varieties. Seed size may also affect oviposition preference of bruchids and a strong correlation has been observed between bruchid resistance and small- or medium-sized seeds with less seed weight (Somta et al., 2007).But Chakraborthy et al. (2004) reported higher seed weight prolonged the development period of pulse bruchid in mungbean.

Biochemical parameters: The biochemical parameters viz., protein, phenol and sugar contents were analysed initially and at eight months after storage in all the selected genotypes and the results were statistically analysed and presented here under.

Protein Content ( $\left.\mathrm{mg} \mathrm{g}^{-1}\right)$ : In fresh seed samples, the maximum $\left(230.97 \mathrm{mg} \mathrm{g}^{-1}\right)$ protein content was found in WGG-42 which was found significantly superior over the other genotypes. Lowest protein content $\left(184.87 \mathrm{mg} \mathrm{g}^{-1}\right)$ was recorded from PM-5 followed by GGG-1 (189.75 $\left.\mathrm{mg} \mathrm{g}^{-1}\right)$ and LGG-607 $\left(188.42 \mathrm{mg} \mathrm{g}^{-1}\right)$ which were found on par with each other (Table 2). There were significant differences in the protein content in different greengram genotypes at eight months after storage. The protein content in seed among greengram genotypes ranged from $162.71 \mathrm{mg} \mathrm{g}^{-1}$ to $215.90 \mathrm{mg} \mathrm{g}^{-1}$. The minimum protein content was recorded in GGG-1 $(162.71 \mathrm{mg}$ $\left.\mathrm{g}^{-1}\right)$ followed by LGG-607 (163.60 $\left.\mathrm{mg} \mathrm{g}^{-1}\right)$ and PM$5\left(164.49 \mathrm{mg} \mathrm{g}^{-1}\right)$ which were found at par with each other. While maximum protein content was recorded in WGG-42 (215.90 $\left.\mathrm{mg} \mathrm{g}^{-1}\right)$ even at eight months after storage (Table 2). The genotypes having higher protein content were much preferred by $C$. chinensiswith more number of eggs/100 seed, high adult emergence along with higher growth index coupled with higher weight loss when compared to genotypes having less protein content (Table.2). The present findings are in accordance with Ushaet al. (2020) who reported that the genotypes with highest protein content recorded highest seed damage and vice versa in mungbean. Chandel and Bhadauria (2015) reported that the varieties with high amount of protein are susceptible to pulse bruchid in pigeonpea.

There was a considerable decrease in protein content in infested seed of all the greengram genotypes due to feeding of $C$. chinensis irrespective of initial protein content. The highest decrease in protein content after 8 months was observed in infested seed of GGG-1 (14.25\%), while minimum reduction in protein content was recorded in WGG-42 (6.52 \%). In corroboration with present study, Reddy and Pushpamma (1986) recorded a substantial decrease in protein content in pigeonpea, chickpea and greengram due to infestation of pulse bruchid. Ushaet al. (2020) reported significant positive correlation between per cent seed damage, per cent weight loss and protein content, starch content and total soluble sugar content in mungbean.

Phenol Content ( $\left.\mathrm{mg} \mathrm{g}^{-1}\right)$ : The phenol content ranged from 5.14 to $19.08 \mathrm{mg} \mathrm{g}^{-1}$ among the greengram genotypes in initial seed samples with significant differences among the genotypes (Table $2)$. The maximum phenol content $\left(19.08 \mathrm{mg} \mathrm{g}^{-1}\right)$ was observed in PM-5, while the minimum phenol content $\left(5.14 \mathrm{mg} \mathrm{g}^{-1}\right)$ was observed in WGG-42 followed by LGG-586 (5.37 $\left.\mathrm{mg} \mathrm{g}^{-1}\right)$. At eight 
Table 1: Physical parameters of different greengram genotypes

\begin{tabular}{|c|c|c|c|c|c|c|c|c|}
\hline Genotypes & $\begin{array}{l}\text { Seed } \\
\text { colour }\end{array}$ & $\begin{array}{c}\text { Seed } \\
\text { surface } \\
\text { texture }\end{array}$ & Seed shape & $\begin{array}{c}\text { Seed } \\
\text { length } \\
(\mathrm{mm})\end{array}$ & $\begin{array}{c}\text { Seed } \\
\text { width } \\
(\mathrm{mm})\end{array}$ & $\begin{array}{c}\text { Seed } \\
\text { length } \\
\text { width } \\
\text { ratio } \\
\end{array}$ & $\begin{array}{c}\text { Seed coat } \\
\text { hardness } \\
(\%)\end{array}$ & $\begin{array}{c}100 \\
\text { seed } \\
\text { weight } \\
(\mathrm{g}) \\
\end{array}$ \\
\hline GGG-1 & $\begin{array}{l}\text { Olive } \\
\text { green }\end{array}$ & Rough & Globose & $4.27^{\mathrm{b}}$ & $3.70^{\mathrm{a}}$ & $1.15^{\mathrm{f}}$ & $\begin{array}{c}57.33 \\
(49.20)^{\mathrm{h}}\end{array}$ & $4.00^{\mathrm{b}}$ \\
\hline LGG-407 & Green & Smooth & Ovoid & $4.10^{c}$ & $3.26^{\mathrm{cd}}$ & $1.26^{\mathrm{bcd}}$ & $\begin{array}{c}83.67 \\
(66.14)^{\mathrm{c}}\end{array}$ & $3.14^{\mathrm{e}}$ \\
\hline LGG-450 & $\begin{array}{l}\text { Thick } \\
\text { green }\end{array}$ & Smooth & Cylindrical & $4.22^{b}$ & $3.21^{\mathrm{de}}$ & $1.32^{\mathrm{a}}$ & $\begin{array}{c}71.33 \\
(57.61)^{\mathrm{de}}\end{array}$ & $3.23^{\mathrm{de}}$ \\
\hline LGG-460 & $\begin{array}{l}\text { Thick } \\
\text { green }\end{array}$ & Wrinkled & Ovoid & $4.25^{\mathrm{b}}$ & $3.25^{\mathrm{cd}}$ & $1.31^{\mathrm{ab}}$ & $\begin{array}{c}91.00 \\
(72.53)^{\mathrm{b}}\end{array}$ & $3.51^{\mathrm{c}}$ \\
\hline LGG-574 & Green & Smooth & Ovoid & $3.95^{\mathrm{ef}}$ & $3.18^{\mathrm{de}}$ & $1.24^{\text {cde }}$ & $\begin{array}{c}62.00 \\
(51.92)^{\mathrm{g}}\end{array}$ & $3.14^{\mathrm{e}}$ \\
\hline LGG-586 & Green & Smooth & Cylindrical & $3.79^{\mathrm{g}}$ & $3.09^{\mathrm{f}}$ & $1.23^{\text {cde }}$ & $\begin{array}{c}68.33 \\
(55.73)^{\text {ef }}\end{array}$ & $3.14^{\mathrm{e}}$ \\
\hline LGG-595 & $\begin{array}{l}\text { Thick } \\
\text { green }\end{array}$ & Rough & Ovoid & $4.00^{\mathrm{de}}$ & $3.32^{\mathrm{c}}$ & $1.20^{\mathrm{def}}$ & $\begin{array}{c}83.67 \\
(66.14)^{\mathrm{c}} \\
\end{array}$ & $3.27^{\mathrm{de}}$ \\
\hline LGG-607 & Green & Rough & Cylindrical & $3.90^{\mathrm{f}}$ & $3.15^{\mathrm{ef}}$ & $1.24^{\text {cde }}$ & $\begin{array}{c}65.33 \\
(53.91)^{\mathrm{fg}} \\
\end{array}$ & $3.34^{\mathrm{d}}$ \\
\hline LGG-610 & $\begin{array}{l}\text { Light } \\
\text { green }\end{array}$ & Rough & Ovoid & $4.12^{c}$ & $3.47^{\mathrm{b}}$ & $1.19^{\mathrm{ef}}$ & $\begin{array}{c}66.33 \\
(54.51)^{\mathrm{fg}}\end{array}$ & $3.66^{\mathrm{c}}$ \\
\hline PM-5 & $\begin{array}{l}\text { Light } \\
\text { olive } \\
\text { green } \\
\end{array}$ & Rough & Oblong & $4.77^{\mathrm{a}}$ & $3.77^{\mathrm{a}}$ & $1.26^{\mathrm{abc}}$ & $\begin{array}{c}96.00 \\
(79.10)^{\mathrm{a}}\end{array}$ & $4.87^{\mathrm{a}}$ \\
\hline TM-92-2 & Green & Smooth & Ovoid & $4.06^{\mathrm{cd}}$ & $3.29^{\mathrm{c}}$ & $1.24^{\text {cde }}$ & $\begin{array}{c}75.33 \\
(60.20)^{\mathrm{d}}\end{array}$ & $3.30^{\mathrm{de}}$ \\
\hline WGG-42 & $\begin{array}{l}\text { Thick } \\
\text { green }\end{array}$ & Smooth & Ovoid & $4.26^{\mathrm{b}}$ & $3.32^{\mathrm{c}}$ & $1.28^{\mathrm{abc}}$ & $\begin{array}{c}74.33 \\
(59.54)^{\mathrm{d}}\end{array}$ & $3.21^{\mathrm{de}}$ \\
\hline Mean & - & - & - & 4.14 & 3.34 & 1.24 & $\begin{array}{c}74.56 \\
(60.54)\end{array}$ & 3.48 \\
\hline F-test & Sig. & Sig. & Sig. & Sig. & Sig. & Sig. & Sig. & Sig. \\
\hline SEm \pm & - & - & - & 0.05 & 0.04 & 0.02 & 0.88 & 0.05 \\
\hline C.D. (5\%) & - & - & - & 0.14 & 0.12 & 0.05 & 2.56 & 0.16 \\
\hline C.V. (\%) & - & - & - & 2.05 & 2.07 & 2.46 & 2.51 & 2.70 \\
\hline
\end{tabular}

Figures in parenthesis are arc sine transformed values

Means in the same column showing similar alphabets are not significant different

months after infestation, the phenol content in seed while minimum reduction was recorded from PMamong the greengram genotypes varied from $1.915(15.09 \%)$ which might be due to low infestation. $\mathrm{mg} \mathrm{g}^{-1}$ to $16.20 \mathrm{mg} \mathrm{g}^{-1}$ with significant differences. The longest mean development period was found PM-5 (16.20 mg g $\mathrm{g}^{-1}$ ) recorded the maximum in PM-5 (33.83 days), while shortest mean phenol content, while the minimum was recorded development period (25.81 days) was recorded on in WGG-42 (1.91 mg g $\left.{ }^{-1}\right)$ which was significantly WGG-42 (Table 2). The results clearly indicated low among all the genotypes. The genotypes with that the genotypes with high phenol content phenol content recorded less number of eggs, prolonged the development period of bruchid hence less adult emergence and growth index together with less seed damage. Hence, from the which resulted in less weight loss as 8 months data it was proved that high phenol content may after storage (Table 2).The overall assessment of confer resistance against bruchids. The phenols phenol content in fresh as well as infested seed may affect the metabolic enzymes in insects as the showed that there was considerable reduction in phenol acts as antimetabolic factor and might have phenol content after bruchid infestation with contributed to resistance mechanism or phenols significant differences among the various may have inhibitory role on the development of $C$. genotypes. The maximum reduction in phenol chinensis. Thepresent findings are in consistency content was recorded from WGG-42 (62.84\%), with Ghosal et al. (2004) who observed retarded 
Table 2: Biochemical properties of greengram genotypes and biological parameters of pulse bruchid during the storage

\begin{tabular}{|c|c|c|c|c|c|c|c|c|c|c|c|c|c|}
\hline \multirow{2}{*}{ Genotypes } & \multicolumn{2}{|c|}{$\begin{array}{l}\text { Protein content } \\
(\mathrm{mg} / \mathrm{g})\end{array}$} & \multicolumn{2}{|c|}{$\begin{array}{l}\begin{array}{l}\text { Phenol content } \\
(\mathrm{mg} / \mathrm{g})\end{array} \\
\end{array}$} & \multicolumn{2}{|c|}{$\begin{array}{l}\text { Total sugar } \\
\text { content }(\mathrm{mg} / \mathrm{g})\end{array}$} & \multirow{2}{*}{$\begin{array}{l}\text { Electrical } \\
\text { conductivity } \\
(\mathrm{dSm}-1) \\
\text { (Initial- 0.4) }\end{array}$} & \multirow{2}{*}{$\begin{array}{l}\text { Moisture } \\
\text { content } \\
(\%) \\
\text { (initial- } \\
9.00)\end{array}$} & \multirow{2}{*}{$\begin{array}{l}\text { Number } \\
\text { of eggs / } \\
100 \\
\text { seed* }\end{array}$} & \multirow{2}{*}{$\begin{array}{l}\text { Adult } \\
\text { emergence } \\
(\%)^{* *}\end{array}$} & \multirow{2}{*}{$\begin{array}{l}\text { Weight } \\
\text { loss } \\
(\%)^{* *}\end{array}$} & \multirow{2}{*}{$\begin{array}{l}\text { Mean } \\
\text { development } \\
\text { period } \\
\text { (days) }\end{array}$} & \multirow{2}{*}{$\begin{array}{l}\text { Growth } \\
\text { index }\end{array}$} \\
\hline & Initial & $\begin{array}{l}\text { After } 8 \\
\text { months }\end{array}$ & Initial & $\begin{array}{l}\text { After } 8 \\
\text { months }\end{array}$ & Initial & $\begin{array}{l}\text { After } 8 \\
\text { months }\end{array}$ & & & & & & & \\
\hline GGG-1 & $189.75^{\mathrm{fg}}$ & $162.71^{\mathrm{e}}$ & $15.16^{\mathrm{c}}$ & $12.40^{\mathrm{c}}$ & $67.27^{\mathrm{f}}$ & $49.43^{\mathrm{f}}$ & 0.84 & $\begin{array}{l}9.31 \\
(17.76) \\
\end{array}$ & $\begin{array}{l}24.96 \\
(5.09)^{\mathrm{g}} \\
\end{array}$ & $\begin{array}{l}40.23 \\
(39.35)^{\mathrm{e}}\end{array}$ & $\begin{array}{l}6.01 \\
(14.18)^{\mathrm{f}}\end{array}$ & $32.72^{\mathrm{a}}$ & $1.23^{\mathrm{f}}$ \\
\hline LGG-407 & $213.68^{b c}$ & $188.42^{\mathrm{c}}$ & $7.44^{\mathrm{i}}$ & $4.45^{\mathrm{g}}$ & $76.38^{\mathrm{c}}$ & $64.49^{b}$ & 1.42 & $\begin{array}{l}9.58 \\
(18.02)\end{array}$ & $\begin{array}{l}52.33 \\
(7.30)^{\mathrm{c}}\end{array}$ & $\begin{array}{l}55.67 \\
(48.24)^{b}\end{array}$ & $\begin{array}{l}19.89 \\
(26.48)^{c}\end{array}$ & $28.56^{\mathrm{d}}$ & $1.95^{\mathrm{c}}$ \\
\hline LGG-450 & $225.20^{\mathrm{ab}}$ & $199.50^{b}$ & $8.25^{\mathrm{h}}$ & $5.48^{\mathrm{f}}$ & $74.00^{\mathrm{cd}}$ & $54.98^{\mathrm{e}}$ & 1.47 & $\begin{array}{l}9.56 \\
(18.00) \\
\end{array}$ & $\begin{array}{l}54.33 \\
(7.44)^{\mathrm{c}}\end{array}$ & $\begin{array}{l}55.80 \\
(48.31)^{b}\end{array}$ & $\begin{array}{l}17.66 \\
(24.84)^{d}\end{array}$ & $26.78^{\mathrm{e}}$ & $2.08^{b}$ \\
\hline LGG-460 & $196.84^{\mathrm{efg}}$ & $175.12^{d}$ & $11.71^{\mathrm{e}}$ & $8.59^{\mathrm{e}}$ & $74.80^{\mathrm{cd}}$ & $61.72^{\mathrm{c}}$ & 1.03 & $\begin{array}{l}9.43 \\
(17.81)\end{array}$ & $\begin{array}{l}37.54 \\
(6.21)^{\mathrm{e}}\end{array}$ & $\begin{array}{l}50.47 \\
(45.25)^{c}\end{array}$ & $\begin{array}{l}9.73 \\
(18.16)^{\mathrm{e}}\end{array}$ & $30.06^{\mathrm{cd}}$ & $1.68^{\mathrm{d}}$ \\
\hline LGG-574 & $210.58^{\mathrm{cd}}$ & $184.43^{\mathrm{c}}$ & $11.01^{\mathrm{f}}$ & $8.59^{\mathrm{e}}$ & $80.74^{b}$ & $57.75^{d}$ & 1.12 & $\begin{array}{l}9.46 \\
(17.90) \\
\end{array}$ & $\begin{array}{l}44.25 \\
(6.73)^{d}\end{array}$ & $\begin{array}{l}51.03 \\
(45.57)^{c}\end{array}$ & $\begin{array}{l}10.07 \\
(18.49)^{\mathrm{e}}\end{array}$ & $29.00^{\mathrm{d}}$ & $1.76^{\mathrm{d}}$ \\
\hline LGG-586 & $226.09^{\mathrm{a}}$ & $199.94^{b}$ & $5.37^{\mathrm{j}}$ & $3.18^{h}$ & $83.91^{\mathrm{ab}}$ & $66.47^{\mathrm{ab}}$ & 1.71 & $\begin{array}{l}9.77 \\
(18.21)\end{array}$ & $\begin{array}{l}61.88 \\
(7.93)^{b}\end{array}$ & $\begin{array}{l}57.64 \\
(49.38)^{b}\end{array}$ & $\begin{array}{l}22.96 \\
(28.62)^{b}\end{array}$ & $26.56^{\mathrm{e}}$ & $2.17^{\mathrm{b}}$ \\
\hline LGG-595 & $199.94^{\mathrm{def}}$ & $174.24^{\mathrm{d}}$ & $15.62^{b c}$ & $11.94^{\mathrm{c}}$ & $68.45^{\mathrm{ef}}$ & $54.19^{\mathrm{e}}$ & 0.75 & $\begin{array}{l}9.30 \\
(17.75)\end{array}$ & $\begin{array}{l}31.79 \\
(5.73)^{f}\end{array}$ & $\begin{array}{l}45.93 \\
(42.64)^{d}\end{array}$ & $\begin{array}{l}6.29 \\
(14.52)^{\mathrm{f}}\end{array}$ & $31.06^{\mathrm{bc}}$ & $1.48^{\mathrm{e}}$ \\
\hline LGG-607 & $188.42^{\mathrm{fg}}$ & $163.60^{\mathrm{e}}$ & $16.20^{\mathrm{b}}$ & $14.13^{\mathrm{b}}$ & $71.23^{\mathrm{de}}$ & $54.19^{\mathrm{e}}$ & 0.84 & $\begin{array}{l}9.34 \\
(17.79)\end{array}$ & $\begin{array}{l}31.17 \\
(5.65)^{\mathrm{f}}\end{array}$ & $\begin{array}{l}34.49 \\
(35.95)^{f}\end{array}$ & $\begin{array}{l}5.80 \\
(13.93)^{\mathrm{f}}\end{array}$ & $32.39^{\mathrm{ab}}$ & $1.06^{\mathrm{g}}$ \\
\hline LGG-610 & $213.24^{\mathrm{bc}}$ & $187.98^{\mathrm{c}}$ & $14.47^{\mathrm{d}}$ & $11.01^{\mathrm{d}}$ & $74.40^{\mathrm{cd}}$ & $59.73^{\mathrm{cd}}$ & 0.87 & $\begin{array}{l}9.27 \\
(17.74)\end{array}$ & $\begin{array}{l}21.88 \\
(4.78)^{\mathrm{g}}\end{array}$ & $\begin{array}{l}31.34 \\
(34.03)^{\mathrm{g}}\end{array}$ & $\begin{array}{l}3.27 \\
(10.40)^{\mathrm{g}}\end{array}$ & $29.45^{\mathrm{cd}}$ & $1.06^{\mathrm{g}}$ \\
\hline PM-5 & $184.87^{\mathrm{g}}$ & $164.49^{\mathrm{e}}$ & $19.08^{\mathrm{a}}$ & $16.20^{\mathrm{a}}$ & $62.51^{\mathrm{g}}$ & $45.86^{\mathrm{g}}$ & 0.69 & $\begin{array}{l}9.20 \\
(17.65)\end{array}$ & $\begin{array}{l}14.00 \\
(3.87)^{h}\end{array}$ & $\begin{array}{l}17.44 \\
(24.67)^{h}\end{array}$ & $\begin{array}{l}0.98 \\
(5.65)^{h}\end{array}$ & $33.83^{\mathrm{a}}$ & $1.05^{\mathrm{h}}$ \\
\hline TM-92-2 & $205.70^{\text {cde }}$ & $179.56^{\mathrm{cd}}$ & $9.17^{\mathrm{g}}$ & $5.60^{f}$ & $72.81^{\mathrm{cd}}$ & $62.11^{\mathrm{c}}$ & 1.07 & $\begin{array}{l}9.53 \\
(17.97)\end{array}$ & $\begin{array}{l}43.54 \\
(6.67)^{d}\end{array}$ & $\begin{array}{l}51.31 \\
(45.73)^{c}\end{array}$ & $\begin{array}{l}10.69 \\
(19.03)^{\mathrm{e}}\end{array}$ & $28.89^{d}$ & $1.78^{\mathrm{d}}$ \\
\hline WGG-42 & $230.97^{\mathrm{a}}$ & $215.90^{\mathrm{a}}$ & $5.14^{\mathrm{j}}$ & $1.91^{\mathrm{i}}$ & $85.10^{\mathrm{a}}$ & $68.06^{\mathrm{a}}$ & 1.84 & $\begin{array}{l}10.04 \\
(17.93)\end{array}$ & $\begin{array}{l}73.17 \\
(8.61)^{\mathrm{a}}\end{array}$ & $\begin{array}{l}63.20 \\
(52.64)^{\mathrm{a}}\end{array}$ & $\begin{array}{l}29.21 \\
(32.70)^{\mathrm{a}}\end{array}$ & $25.81^{\mathrm{e}}$ & $2.83^{\mathrm{a}}$ \\
\hline F-test & Sig. & Sig. & Sig. & Sig. & Sig. & Sig. & Sig. & Sig. & Sig. & Sig. & Sig. & Sig. & Sig. \\
\hline SEm \pm & 3.98 & 2.86 & 0.22 & 0.23 & 1.28 & 0.79 & 0.02 & 1.04 & 0.11 & 0.65 & 0.35 & 0.54 & 0.04 \\
\hline C.D. (5\%) & 11.63 & 8.34 & 0.64 & 0.66 & 3.75 & 2.31 & 0.07 & 3.04 & 0.31 & 1.89 & 1.01 & 1.58 & 0.11 \\
\hline C.V. (\%) & 3.33 & 2.71 & 3.31 & 4.53 & 2.99 & 2.36 & 3.41 & 2.78 & 2.93 & 2.63 & 3.16 & 3.16 & 4.14 \\
\hline
\end{tabular}

Means in the same column showing similar alphabets are not significantly different 
growth and development of $C$. chinensis on legume seed with high phenol content. The soybean genotypes with high amount of phenols showed resistant against bruchids due to their antinutritional activity and by inhibiting the growth of larvae by blocking and disturbing the metabolic pathways (Sharma and Thakur, 2014).

Total Sugar Content (mg $\left.\mathrm{g}^{-1}\right)$ : Significant variation in total sugar content was noticed among different greengram genotypes. In fresh seed samples, maximum total sugar content) was recorded in WGG-42(85.10 $\mathrm{mg} \mathrm{g}^{-1}$ followed by LGG-586 (83.91 $\left.\mathrm{mg} \mathrm{g}^{-1}\right)$. The total sugar content was low in PM-5 (62.51 $\left.\mathrm{mg} \mathrm{g}^{-1}\right)$ which was significantly inferior among all the other genotypes (Table 2).At eight months after infestation, the total sugar content in seed ranged from $45.86 \mathrm{mg} \mathrm{g}^{-1}$ to $68.06 \mathrm{mg} \mathrm{g}^{-1}$ with significant differences among the greengram genotypes. The total sugar content was minimum in PM-5(45.86 $\left.\mathrm{mg} \mathrm{g}^{-1}\right)$ and maximum in WGG-42(68.06 $\left.\mathrm{mg} \mathrm{g}^{-1}\right)$ at eight months after storage also (Table 2). The total sugar content in fresh as well as infested seed showed that there was considerable reduction in total sugar content after infestation. Sugar content in seed decreased to maximum extent in infested seed of LGG-574 (28.47\%), while minimum reduction was observed in TM-92-2 (14.69 \%). PM-5 was the least preferred genotype by pulse bruchid which recorded significantly lowest adult emergence and longest mean development period $(17.44 \%$ and 33.83 days) which had low total sugars. While WGG-42 was found as highly preferred genotype by pulse bruchid with highest adult emergence and shortest mean development period $(63.20 \%$ and 25.81 days) among the different genotypes which recorded highest total sugar content. Hence, from the data, it is evident that the genotypes of greengram having higher sugar content are much preferred by $C$. chinensis. The results are in harmony with Neog and Singh (2011) who reported that the total sugar content showed a positive influence on host suitability with high growth index and high seed infestation by pulse bruchid. Vijay (2000) recorded slight decrease in total soluble sugar in maize and soybean after 15 months of storage.

Electrical conductivity of Seed Leachates (dSm1):: The pooled data after 8 months of storage showed that the genotype, PM-5 recorded significantly lowest electrical conductivity (0.69 $\mathrm{dSm}-1)$. The other genotypes which recorded low electrical conductivity were GGG-1 $(0.84 \mathrm{dSm}-1)$, LGG-607 (0.84 dSm-1) and LGG-610 (0.87 dSm1) and were found at par with each other. The genotype, WGG-42 (1.84 dSm-1) recorded significantly high electrical conductivity followed by LGG-586 (1.71 dSm-1). The data clearly indicated that the genotypes which recorded high moisture content showed higher electrical conductivity and higher weight loss and vice-versa. The variation in electrical conductivity was mainly due to variation in infestation level and also inherent response of each genotype to the attack of bruchid. Electrical conductivity is negatively related to seed quality, higher the value of electrical conductivity lower is the seed quality and lower the field emergence (Amrit et al., 2016). Similar resultswith respect to electrical conductivity was reported by Patil et al. (2003) in chickpea, Bhaduria and Jakhmola (2006) in cowpea and Parameshwarappa et al. (2007) in chickpea.

Seed moisture content: The pooled data after 8 months of storage showed that moisture content was low in PM-5 $(9.40 \%)$ followed by LGG-610 (9.50 \%), GGG-1 (9.60 \%) and LGG-607 (9.60\%). While the moisture content was high in WGG-42 $(11.17 \%)$.While maximum moisture content (10.04 \%) was recorded in WGG-42 among the different genotypes. The results indicated that the genotypes with more moisture content favour the development of bruchid and also recorded higher weight loss. The present results are in accordance with earlier report as the genotypes with high moisture content recorded higher damage after eight months after storage and vice-versa. Choudhary et al. (2017) reported that higher the per cent of moisture content, higher the infestation of seed in lentil.

\section{Correlation Analysis}

The results of simple correlation analysis between the biological parameters of pulse bruchid and physicochemical properties of seed are presented in Table 3. The correlation studies revealed that the eggs lying by bruchid exhibited highly significant positive correlation with protein content $(\mathrm{r}=$ 0.834), sugar content $(r=0.856)$, electrical conductivity $(r=0.934)$ and moisture content $(r=$ 0.930 ). While it was highly significant and negative with 100 seed weight $(r=-0.792)$ and phenol content $(r=-0.955)$. Negative correlation was 
Table 3: Correlation between biological parameters of pulse bruchid and physicochemical properties of greengram seed

\begin{tabular}{|c|c|c|c|c|c|c|c|}
\hline Parameters & $\begin{array}{l}\text { Seed coat } \\
\text { hardness }\end{array}$ & $\begin{array}{l}100 \text { seed } \\
\text { weight }\end{array}$ & $\begin{array}{l}\text { Protein } \\
\text { content }\end{array}$ & $\begin{array}{l}\text { Phenol } \\
\text { content }\end{array}$ & $\begin{array}{l}\text { Sugar } \\
\text { content }\end{array}$ & $\begin{array}{l}\text { Electrical } \\
\text { conductivity }\end{array}$ & $\begin{array}{l}\text { Moisture } \\
\text { content }\end{array}$ \\
\hline Number of eggs laid/ 100 seed & -0.251 & $-0.792^{* *}$ & $0.834^{* *}$ & $-0.955^{* *}$ & $0.856^{* *}$ & $0.934^{* *}$ & $0.930^{* *}$ \\
\hline Adult emergence & -0.290 & $-0.843^{* *}$ & $0.751^{* *}$ & $-0.905^{* *}$ & $0.781^{* *}$ & $0.811^{* *}$ & $0.813^{* *}$ \\
\hline Mean development period & 0.263 & $0.723^{* *}$ & $-0.974^{* *}$ & $0.941^{* *}$ & $-0.873^{* *}$ & $-0.911^{* *}$ & $-0.856^{* *}$ \\
\hline Growth index & -0.071 & $-0.600^{*}$ & $0.832^{* *}$ & $-0.919^{* *}$ & $0.794^{* *}$ & $0.932^{* *}$ & $0.954^{* *}$ \\
\hline
\end{tabular}

**Significant at $1 \%$ level

*Significant at $5 \%$ level

Table 4: Regression analysis between biological parameters of pulse bruchid and physico-chemical properties ofgreengram seed

\begin{tabular}{|c|c|c|}
\hline Parameters & Regression analysis & $\mathbf{R}^{2}$ value (\%) \\
\hline Number of eggs & $Y=2.52-2.825 X_{1}-0.507 X_{2}+16.426 X_{3}-5.527 X_{4}+7.238 X_{5}+0.456 X_{6}+0.273 X_{7}$ & $87.19 *$ \\
\hline Adult emergence & $Y=23.729-18.618 X_{1}-3.088 X_{2}+84.393 X_{3}-29.932 X_{4}+37.706 X_{5}+2.263 X_{6}+1.366 X_{7}$ & $65.81 *$ \\
\hline Mean development period & $Y=36.442+5.458 X_{1}+0.853 X_{2}-35.296 X_{3}+10.029 X_{4}-13.58 X_{5}-0.819 X_{6}-0.464 X_{7}$ & $82.98 *$ \\
\hline Growth index & $\mathrm{Y}=0.188-0.313 \mathrm{X}_{1}-0.151 \mathrm{X}_{2}+6.411 \mathrm{X}_{3}-2.082 \mathrm{X}_{4}+2.628 \mathrm{X}_{5}+0.178 \mathrm{X}_{6}+0.11 \mathrm{X}_{7}$ & $86.82 *$ \\
\hline
\end{tabular}

*Significant at $5 \%$ level $(P=0.005)$

$X_{1}$ - Seed coat hardness; $\quad X_{2}-100$ seed weight; $\quad X_{3}$ - Protein content $(\mathrm{mg} / \mathrm{g}) ; \quad \mathrm{X}_{4}$ - Phenol content $(\mathrm{mg} / \mathrm{g})$;

$X_{5}$ - Sugar content $(\mathrm{mg} / \mathrm{g}) ; X_{6}$ - Electrical conductivity; $X_{7}$ - Moisture content 
noticed between eggs laid / 100 seeds and seed coat hardness $(r=-0.251)$ but it was non-significant. The present results are in agreement with the findings of Pankaj and Singh (2011) who reported that the seed characters such as seed coat thickness, colour and texture of seed coat had no significant influence on ovipositional preference by pulse bruchid on different pulse seeds. Somta et al. (2008) also observed non-significant role of seed coat thickness on oviposition by pulse bruchid. Usha et al. (2020) reported significant positive correlation between per cent seed damage, per cent weight loss and protein content, starch content, total soluble sugar content in mungbean. Similar to egg laying, adult emergence exhibited highly significant positive correlation with protein content $(r=$ 0.751), sugar content $(\mathrm{r}=0.781)$, electrical conductivity $(\mathrm{r}=0.811)$ and moisture content $(\mathrm{r}=$ 0.813 ), while highly significant negative correlation was observed with 100 seed weight $(r=-0.843)$ and phenol content $(\mathrm{r}=-0.905)$. Non-significant negative correlation was noticed between adult emergence and seed coat hardness $(r=-0.290)$. The results are in concurrence with Srinivas (1980) who found a positive significant correlation between protein content in grain and the number of $C$. maculatus adults emerged in different red gram varieties. In contrast to egg laying and adult emergence, the mean development period exhibited highly significant positive correlation with 100 seed weight $(\mathrm{r}=0.723)$ and phenol content $(\mathrm{r}=0.941)$, while highly significant negative correlation with protein content $(r=-0.974)$, sugar content $(r=$ $0.873)$, electrical conductivity $(\mathrm{r}=-0.911)$ and moisture content $(\mathrm{r}=-0.856)$. Non-significant positive correlation was noticed between mean development period and seed coat hardness $(\mathrm{r}=$ 0.263 ).

Growth index exhibited highly significant positive correlation with protein content $(r=0.832)$, sugar content $(r=0.794)$, electrical conductivity $(r=$ $0.932)$ and moisture content $(\mathrm{r}=0.954)$, while highly significant negative association was noticed with phenol content $(\mathrm{r}=-0.919)$ and significant negative correlation was observed with 100 seed weight $(\mathrm{r}=-0.600)$. There was a negative correlation between growth index and seed coat hardness $(\mathrm{r}=-0.071)$ which was non-significant.
The results are in corroboration with that of Soumia et al. (2015) who reported that the biochemical parameters such as phenol and tannin contents had negative relation, while crude protein, soluble protein and starch contents had positive relation with growth index.

\section{Regression Analysis}

Multiple linear regression analysis between growth parameters of pulse bruchid and physicochemical properties of different greengram genotypes (Table 4) revealed that all the physical and chemical properties viz., seed coat hardness, 100 seed weight, protein content, phenol content, total sugar content, electrical conductivity and moisture content together were responsible for 87.19 percent variation in egg laying i.e., number of eggs/ 100 seed by pulse bruchid. However, neither physical properties nor biochemical factors had no significant influence of individually on growth parameters of pulse bruchid. But, all the properties put together were responsible for significant variation in adult emergence (65.81 \%), mean development period $(82.98 \%)$ and growth index $(86.82 \%)$ of pulse bruchid.

\section{Conclusion}

Greengram genotypes with rough and wrinkled texture, oblong or globose shape and light coloured seed might be less preferred by the pulse bruchid for egg laying. The greengram genotypes having low sugar content, low protein content and high phenol content were found resistant against pulse bruchid with less adult emergence, low growth index and less seed weight loss. Growth parameters of pulse bruchid such as egg laying, adult emergence and growth index had significant positive association with protein content and sugar content and significant negative association with phenol content. The mean development period had significant negative association with protein content and sugar content, while significant positive association with phenol content. Among the physical parameters, seed coat hardness had no significant influence on any of growth parameters. Electrical conductivity and moisture content of seed had significant positive influence on egg laying and adult emergence. 


\section{References}

Amrit, L., Katiyar P. K.,Natarajan, S. \&Sripathy K. V. (2016). Relationship among some seed characters, laboratory germination and field emergence in chickpea (Cicerarietinum L.) genotypes differing in testacolour.Journal of Food Legumes. 29(1): 29-32.

Bhadauria, N.S \&Jakhmola, S.S. (2006).Effect of intensity of infestation caused by pulse beetle on extent of losses and germination of seeds in different pulses.Indian Journal of Entomology. 68 (1): 92-94.

Bhise, H. T., Desai, B. B \&Chavan, U. D. (1996).Assessment of some biochemical parameters responsible for shoot fly resistance in sorghum. Journal of Maharashtra Agricultural Universities. 21 (1): 127-129.

Chakraborthy, J. N., Chaudhuri, N.\&Senapathi, S. K.(2004). Correlation between seed parameters and relative susceptibility of mungbean genotypes to Callosobruchuschinensis(L) during storage. Annals of plant Protection Sciences.12: 48-50.

Chakraborthy, S.\&Mondal, P.(2016). Physico chemical parameters of pulses affecting the bruchid (Callosobruchuschinensis(L).) infestation.Asian Journal of Science and Technology. 7 (3): 2554-2560.

Chandel,B. S.\&Bhadauria, D. S. (2015). Impact of bio chemical parameters on pigeon pea varieties against egg laying, fecundity and viability of pulse beetle, Callosobruchuschinensis(L).Journal of Entomological and Zoological studies. 3: 160-165.

Choudhary, S., Bhargava, M.C., Yadav, M.K., Jat, G.C and Choudhary, M.D. (2017).Qualitative losses in different varieties of lentil caused by the infestation of Callosobruchuschinensis.International Journal of Current Microbiology and Applied Sciences.6 (6): 2044-2048.

Dubois, M., Gilles, K.A., Hamilton, J.K., Robers, P.A \&Smith, F. (1956).Estimation of total soluble sugars.Journal of Analytical Chemistry.26: 350.

Dabi, R.K., Gupta, H.C \& Sharma, S.K. (1979).Relative susceptibility of some cowpea varieties to pulse beetle, Callosobruchusmaculatus F. Indian Journal of Agricultural Sciences. 49 (1): 48-50.

Fletcher, T.B \&Ghosh, C.C. (2002).Stored grain pests. Rep. Proc. 3rd Ent. Meeting, Pusa, New Delhi, pp. 712-716.

Ghosal, T.K., Dutta, S., Senapati, S.K \& Deb, D.C. (2004). Role of phenol contents in legume seed and its effect on the biology of Callosobruchuschinensis. Annals of Plant Protection Sciences. 12 (2): 425-475.

Jat N. R, Rana B. S.\&Jat S. K. (2013). Estimation of losses due to pulse beetle in chickpea.The biosacn.8: 861-863.
Lattanzio, V., Terzano, R., Cicco, N., Cardinali, A., Di Venere, D \&Linsalata, V. (2005). Seed coat tannins and bruchid resistance in stored cowpea seeds.Journal of the Science of Food and Agriculture. 85: 839-846.

Lowry, A.H., Rosebrough, N.J., Farr, A.L \& Randall, R.J. (1951).Protein measurement with folin-phenol reagent.Journal of Biological Chemistry. 193: 265-275.

Neog P \& Singh H. K. (2011). Correlation of seed characters of pulses with host suitability and preference of Callosobruchuschinensis(L). Indian Journal of Entomology. 73: 365-370.

Pankaj, N \& Singh, H.K. (2011).Correlation of seed characters of pulses with host suitability and preference of $C$. chinensis (L.).Indian Journal of Entomology. 73: 365-370.

Panse, V.G \&Sukhatme, P.V. (1985).Statistical Methods for Agricultural Workers.Indian Council of Agricultural Research, New Delhi.205-210.

Parameshwarappa, S.G., Deshpande, V.K \&Salimath, P.M. (2007).Studies on comparative response and seed quality attributes of certain chickpea varieties to pulse beetle, (Callosobruchuschinensis L.) in storage.Karnataka Journal ofAgricultural Sciences. 20 (3): 492-495.

Patil, S.K., Tanpure, S.V \& Mate, S.N. (2003).Effect of different levels of pulse beetle infestation on chickpea during storage.Seed Research. 31 (1): 119-120.

Rai, P.C \& Singh, J. (1989). Relative susceptibility of chickpea (Cicer arietinum) varieties to pulse beetle (Callosobruchus chinensis). Indian Journal of Agricultural Sciences. 59 (2): 135-136.

Reddy, M.U and Pushpamma, P. (1986). Effect of storage on aminoacid and biological quality of proteins in different varieties of pigeonpea, greengram and chickpea. Nutrition Reports International. 33 (6): 1021-1028.

Satyavir, V.(1980). Ovipositional response and development of Callosobruchus maculatus F. on different varieties of cowpea. Bulletin Grain Technology. 18 (3): 200-203.

Shaheen, F.A. (2006). Integrated management of pulse beetle, Callosobruchuschinensis L. (Coleoptera: Bruchidae) attacking stored chickpea. M. Sc. (Agri.) Thesis.University of Arid Agriculture, Rawalpindi, Pakistan. 226.

Sharma,S.\&Thakur, D. R.(2014).Bio chemical basis for bruchid resistance in cowpea, chickpea and soybean genotypes. American journal of Food Technology 9 (6): 318-324.

Singh, B.D. (2002). Plant Breeding: Principles and Methods; Kalyani Publishers: New Delhi, India. 587-591. 
Singhal, S.K \& Singh, R. (1985). Relative susceptibilty of promising varieties of chickpea and greengram to pulse beetle, Callosobruchus chinensis Linn. Bulletin Grain Technology. 23 (1): 28-32.

Somta, P., Ammaranan, C., Ooi, P.A.C \&Srinivas, P. (2008).Inheritance of seed resistance to bruchids in cultivated mungbean (Vigna radiate L. Wilczek).Euphytica. 155: 47-55.

Somta, C., Somta, P., Tomooka, N., Ooi, P. A. C., Vaughan, D. A., \& Srinives, P. (2007). Characterization of new sources of mungbean (Vigna radiata (L.) Wilczek) resistance to bruchids, Callosobruchus spp. (Coleoptera: Bruchidae). Journal of Stored Products Research. 44: 316321.

Soumia, P.S., Srivastava, G.C., Guru, P.P \& Subramanian, P. (2015). Physical and biochemical basis of resistance in mungbean accessions against Callosobruchusmaculatus (F.). International Conference on Innovative Insect Management Approaches for Sustainable Agro Ecosystem. 272: 31-34.

Srinivas, G. (1980). Studies on the effect of physico-chemical characters of few pigeonpea varieties on oviposition and development of pulse beetle, Callosobruchusmaculatus(F.)
M.Sc. (Ag.) Thesis. Andhra Pradesh Agricultural University, Hyderabad.

Steel, R.G.D \&Torrie, J.G. (1980).Principles and procedures of statistics.McGraw Hill Book Inc. New York.

Swain, T.\&Hillis, W.E. (1959). The phenolic constituents of Prunusdomestica. L. The quantitative analysis of phenolic constituents. Journal of the Science of Food and Agriculture.10: 63-68.

Usha R, Singh, P.S., Singh, S. K. \&Saxena R.P.N. (2020). Biochemical basis of resistance in greengram genotypes against pulse beetle, Callosobruchusmaculatus(F.)under storage conditions. Journal of Entomological Research, 44 (4):541-546

Vijay, D. (2000). Relationship between physico-chemical parameters and the deterioration mechanism in maize and soybean seeds.M.Sc.Thesis. Indian Agricultural Research Institute, New Delhi.

Yadav, D.S., Panwar, K.S. and Sing, V.K. (1994). Management of pulse crops in sequential cropping. Indian Abst.Proc.Intercropping.Symposium on pulse Research. 26 April, New Delhi, India. 27p. 